\title{
GRATIEN DU PONT, Les Controverses des Sexes Masculin et Femenin
}

\section{Maurizio Busca}

\section{OpenEdition}

\section{Journals}

\section{Édition électronique}

URL : https://journals.openedition.org/studifrancesi/22466

DOI : $10.4000 /$ studifrancesi.22466

ISSN : 2427-5856

\section{Éditeur}

Rosenberg \& Sellier

\section{Édition imprimée}

Date de publication : 1 avril 2020

ISSN : 0039-2944

\section{Référence électronique}

Maurizio Busca, " GRATIEN du Pont, Les Controverses des Sexes Masculin et Femenin », Studi Francesi [En ligne], 190 (LXIV | I) | 2020, mis en ligne le 01 avril 2020, consulté le 03 août 2021. URL : http:// journals.openedition.org/studifrancesi/22466; DOI : https://doi.org/10.4000/studifrancesi.22466

Ce document a été généré automatiquement le 3 août 2021

\section{(c) (i) $\odot$}

Studi Francesi è distribuita con Licenza Creative Commons Attribuzione - Non commerciale - Non opere derivate 4.0 Internazionale. 


\title{
GRATIEN DU PONT, Les Controverses des Sexes Masculin et Femenin
}

\author{
Maurizio Busca
}

\section{RÉFÉRENCE}

GRATIEN DU PONT, Les Controverses des Sexes Masculin et Femenin, éd. C. Marcy, Paris, Classiques Garnier , 2017, «Textes de la Renaissance» 204, 1018 pp.

1 Le Controverses di Du Pont vengono pubblicate per la prima volta in un'edizione moderna, riccamente annotata e commentata, basata sul testo dell'editio princeps apparsa a Toulouse per i tipi di Jacques Colomiès nel 1534 (tale scelta deriva dall'interesse dell'apparato paratestuale della princeps, più ampio di quello delle edizioni successive del 1536-1541). La corposa introduzione (pp.9-316) si apre con un capitolo dedicato alla biografia dell'autore e soprattutto alla sua rete di relazioni: $\mathrm{Du}$ Faur, La Perrière e D'Auriol, ma anche Dolet, la cui ostilità e il cui giudizio impietoso espresso nei suoi epigrammi peseranno per secoli sulla memoria di Du Pont. I capitoli seguenti richiamano l'attenzione sull'opera edita. La curatrice del volume difende la tesi secondo cui le Controverses non sarebbero l'espressione di una querelle des femmes strettamente tolosana: pur essendo profondamente legate al contesto locale, andrebbero piuttosto inserite nel quadro di un dibattito sui sessi di portata nazionale. Nel corso delle analisi, vengono sottolineate le particolarità di un testo che si presenta come una compilazione di materiali ampiamente debitori della tradizione vernacolare misogina medievale e cinquecentesca, inseriti in una cornice informata dal modello del dibattito giudiziario. Allo studio delle fonti e dei modelli si affianca quello di dispositivi retorici e poetici impiegati dall'autore, essenzialmente fedeli a quelli elaborati nell'ambito della Grande rhétorique. Si segnalano la presenza di un'appendice iconografica e di un ricco glossario, oltre agli indici e a un'estesa bibliografia. 